\title{
OBSERVATIONS ON DYNAMICS OF FORAGING HOLE CONSTRUCTION OF TWO LEAF-FEEDING, SOIL-INHABITING Syntermes SPECIES (INSECTA: ISOPTERA) IN AN AMAZONIAN RAINFOREST, BRAZIL
}

\author{
Christopher MARTIUS', Matthias WELLER ${ }^{2}$
}

\begin{abstract}
The intensity of construction of foraging access holes by two leaf-litter feeding, soil- inhabiting termite species, Syntermes molestus and Syntermes spinosus, in a Central Amazonian rain forest, was observed on consecutive nights for two weeks. Between 11 and 48 nest entrances per $\mathrm{m}^{2}$ were counted. Interaction between the two species was intense; some entrance holes were overtaken by the larger species during the observations; however, both species coexist in the area. A calculated minimum of 35 entrances $/ \mathrm{m}^{2}$ is built every year by both species, emphasizing the importance of soil-burrowing termites for soil structure, aeration and water regime.
\end{abstract}

Key Words: Leaf-litter feeding termites, soil-inhabiting termites, burrowing activity, soil density

Observações sobre a Dinâmica de Construção de "Olheiros" em Duas Espécies de Cupins Subterrâneos, Comedores de Folhas do Gênero Syntermes (Insecta: Isoptera) numa Floresta Amazônica, Brasil.

RESUMO - A intensidade de construções de saidas de forrageamento em duas espécies de cupins subterrâneos que se alimentam de serrapilheira, Syntermes molestus e $S$. spinosus, numa floresta tropical úmida da Amazônia Central, foi observada em noites consecutivas durante duas semanas. Foram contadas entre 11 e 48 entradas de ninho por $\mathrm{m}^{2}$. A interação entre as duas espécies foi intensa; alguns dos olheiros foram conquistados pela espécie maior durante as observações; mesmo assim, ambas espécies coexistem na área. Um mínimo calculado de 35 entradas $/ \mathrm{m}^{2}$ é construido cada ano por ambas as espécies, o que enfatiza a importância de cupins de solo para a estrutura, aeração e regime hídrico do solo.

Palavras-chave: Cupins comedores de serrapilheira, cupins de solo, atividade de escavação, densidade de solo.

\section{INTRODUCTION}

Leaf-litter feeding termites of the species Syntermes molestus and $S$. spinosus are abundant in the primary rain forest of the "Reserva Florestal Adolfo Ducke" in central Amazonia (Martius, 1998). These species forage at night on the forest floor where they cut pieces out of dead leaves which they carry to their nests (Bandeira, 1991). The density of foraging groups of both species on this site has been assessed by Barbosa (1993), but many aspects of their foraging behaviour remained unknown. It was reported that Syntermes nests may reach $3 \mathrm{~m}$ down in the soil (Constantino, 1995) and that the subterranean nest chambers are interconnected by galleries forming a foraging territory which extends over tens of square meters (Darlington, 1995; Martius, unpubl.). As the outlines of the totally subterra-

1 II. Zoologisches Institut, Universität Göttingen, Berliner Str. 28, D-37073 Glöttingen, Germany [present address: ZEF, University of Bonn, Walter - Flex - Str. 3, D-53113 Bonn, Germany]

2 Tessinstr. 33, D-72072 Tübingen, Germany 
nean nests are not discernible in the forest, we mapped the presence of nest entrances on a small plot and the activity of the termites at and around these entrances for 13 days. During these observations, we discovered an unexpectedly high activity of foraging holes construction in both species.

\section{MATERIAL AND METHODS}

The study was carried out in the rain forest reserve "Reserva Florestal Adolfo Ducke", in Central Amazonia, near the city of Manaus. The reserve is covered by dense "terra firme" rain forest (Prance, 1990); the soil is mostly a nutrient-poor yellow clayey latosol (oxisol) (Chauvel et al., 1987). The climate is characterized by a short "dry" season (=monthly precipitation $<100 \mathrm{~mm}$ ) from July to September. The 1911-1990 average annual rainfall was $2107 \mathrm{~mm}$ in the region of Manaus, and average minimum and maximum air temperatures were 20 and $26^{\circ} \mathrm{C}$, respectively ((Ribeiro, 1991). Information on leaf litter stocks is given in Höfer et al. (1996).

The density of foraging holes of Syntermes nests was determined on 8 plots of $1 \mathrm{~m}^{2}$ each, distributed at random throughout an area of $5 \mathrm{~km}^{2}$ of the Reserva Ducke. The litter quantity at each plot was only visually estimated.

We made observations of the foraging activity of two termite species, Syntermes spinosus and Syntermes molestus in a separate area which totalled $68 \mathrm{~m}^{2}$ (Fig. 1). Specimens of both termites were collected for identification in this area before the obser- vation period. During a total period of 13 nights, we visited this area on 8 nights for observations and mapping of the active exit holes (entrances from which groups of foraging termites were seen emerging) of both species. During the observations, termites were left undisturbed as much as possible; they were identified by eye according to their size. The exit holes were mapped, numbered for re-identification and marked with little flags stuck into the soil near the entrances. Observations were carried out for approximately one hour each night.

\section{RESULTS AND DISCUSSION}

In areas where the two Syntermes species are active, we counted between 11 and 48 foraging holes per $\mathrm{m}^{2}$ (Tab. 1 ); but we could not determine which of the species had built them. Although some of the holes may have been produced by other soil-burrowing animals, most of them are of the typical size and shape of Syntermes nest entrances. We found no relationship between the number of holes and the amount of litter available; however, a possible correlation may have been obscured by the fact that we could not distinguish between recent and old, active and abandoned entrance holes. The density of active foraging holes, as determined in the area where the foraging dynamics were observed, was much lower; from about 0.15 holes $/ \mathrm{m}^{2}$ at the beginning to 0.29 holes $/ \mathrm{m}^{2}$ at the end of the observation period of two weeks. Here, litter quantity was not assessed.

Excavations of nest foraging 
Table 1. Number of foraging holes of Syntermes spp. (indet.) counted per square meter in the Reserva Ducke. Litter quantity: + low, ++ high (assessed by eye).

\begin{tabular}{lcc}
\hline Area & total holes $/ \mathrm{m}^{2}$ & litter quantity \\
\hline 1 & 48 & ++ \\
$2^{\circ}$ & 29 & ++ \\
3 & 14 & ++ \\
4 & 26 & + \\
5 & 24 & + \\
6 & 28 & + \\
7 & 11 & ++ \\
$8^{*}$ & 25 & ++ \\
\hline
\end{tabular}

' = area with dense root mat, difficulting roper assessment of entrances

holes of undetermined Syntermes species showed that these generally lead to small chambers of oval groundplan, $1-2 \mathrm{~cm}$ high and $5-10 \mathrm{~cm}$ in diameter, in which stockpiles of leaf "chips" can sometimes be found which have been cut out of the litter by the termites and deposited here. The walls of these chambers and of the galleries leading to them are generally made out of clay and show no linings of organic matter. From these chambers, which may be interconnected beneath the soil surface, galleries lead further down, presumably to the nest. During the day, some of the nest entrances may be found closed by a wall made out of fresh clay, others are left open. In the latter case, however, we found that the entrance is often obstructed by a wall at a place deeper down in the nest system.

Generally, termites leave the foraging holes at night, between 19:00 and $02: 00 \mathrm{~h}$, in large foraging columns consisting of workers protected by soldiers, as described by Barbosa (1993).

We started to observe the foraging activity and to mark active nest holes with little flags stuck next to them in one area of forest on 22-VII-1994. Almost all of these holes were abandoned the next night, and many new foraging holes were constructed. We then started to observe the reconstruction of foraging holes and the activities of the termites in this area for 8 nights during a period of 13 nights. In this period, the number of marked entrances within the observation area increased from 11 (9 of Syntermes molestus and 2 of $S$. spinosus) to 89 , an average of 6.5 entrances constructed per night. However, at the end of the observed period, only 15 holes were active ( 8 of S. molestus and 7 of S. spinosus) (Fig. 1). The maximum observed number of active exit holes was 20 (on 22-VII); the average was 14.4 active holes per night. The map of all exit holes marked during the observations (Fig. 2) shows that although there were concentrations of foraging holes of $S$. molestus in the NE part of the area (right center of the figure) and of $S$. spinosus in the northernmost part (upper left of the figure), nest entrances of both species were distributed throughout the area, and were often situated close to each other. The users of some of the holes changed; two exit holes from which $S$. molestus foragers were emerging on 24 VII had been taken over by $S$. spinosus on 26-VII.

The rate of re-usage of the exit holes was low; 69 holes $(78 \%)$ were used only once, $16(18 \%)$ were used twice, $3(4 \%)$ were used 3 times, and only one was used more than that $(5$ times was the maximum number of usages observed).

The low rate of re-usage and the 
large rate of rebuilding of exit holes is interestihg and may be a result of aggressive interactions between both species. In the laboratory, they fight fiercely when they meet, but this may be due to the confinement, and mutual avoidance upon encounters may be a more natural behaviour. The vicinity of exit holes and foraging areas of the two species leads to frequent encounters. Two exit holes which were originally used by $S$. molestus were taken over by the larger species, $S$. spinosus; however, both species coexist apparently in stable assemblages. However, we can not rule out the possibility that the disturbance by our frequent observations with head lanterns induced a stronger building behaviour in the termites.

The difference between the number of entrances (Tab. 1) and the number of active exit holes on the obser-

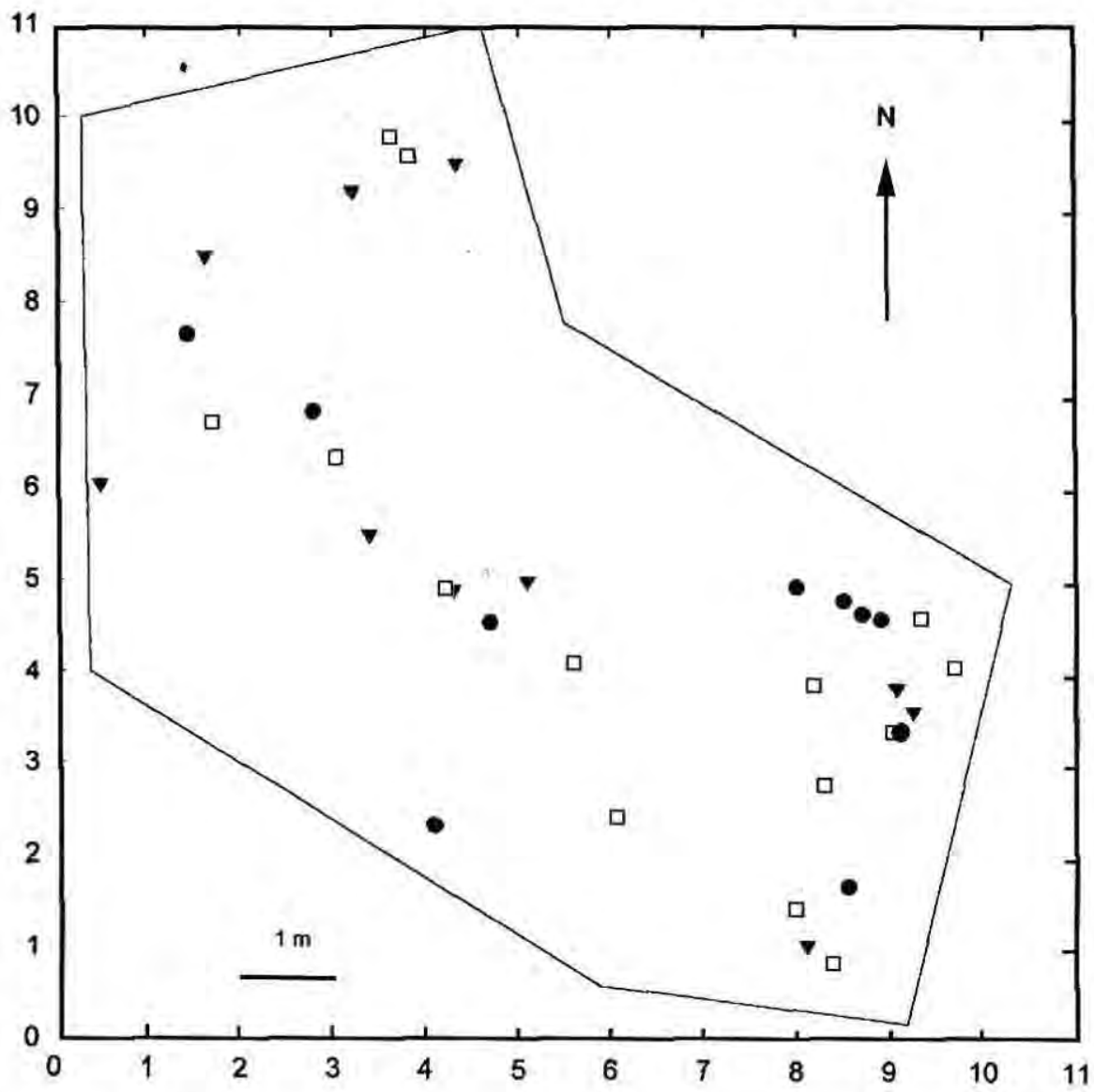

Figure 1. Nest entrance holes of Syntermes molestus and $S$. spinosus mapped in an area of $68 \mathrm{~m}^{2}$ in - the Reserva Florestal Adolfo Ducke, Central Amazonia, during 13 nights. In this map, no difference is made between species. Filled triangles = active entrances mapped on $22 \mathrm{July}$, open squares $=$ active entrances on 27 July, filled circles $=$ active entrances on 4 August. The map shows that only a few entrances were re-used. 
vation plot points to the importance soil-burrowing arthropods like termites may have on physical soil properties (e.g. water uptake capacity, aeration of soils), as in the clayey soil these constructions persist for a long time even after having been abandoned by their architects. During our observations, 78 exit holes were constructed in an area of $68 \mathrm{~m}^{2}$ during 12 nights, which corresponds to 35 new exit holes per $\mathrm{m}^{2}$ per year if a steady construction activity is assumed throughout the year. This may not be the case, as the construction activity may be slowed down during the dry season, but the holes are only indicators of much larger termitogenous soil movements occur-

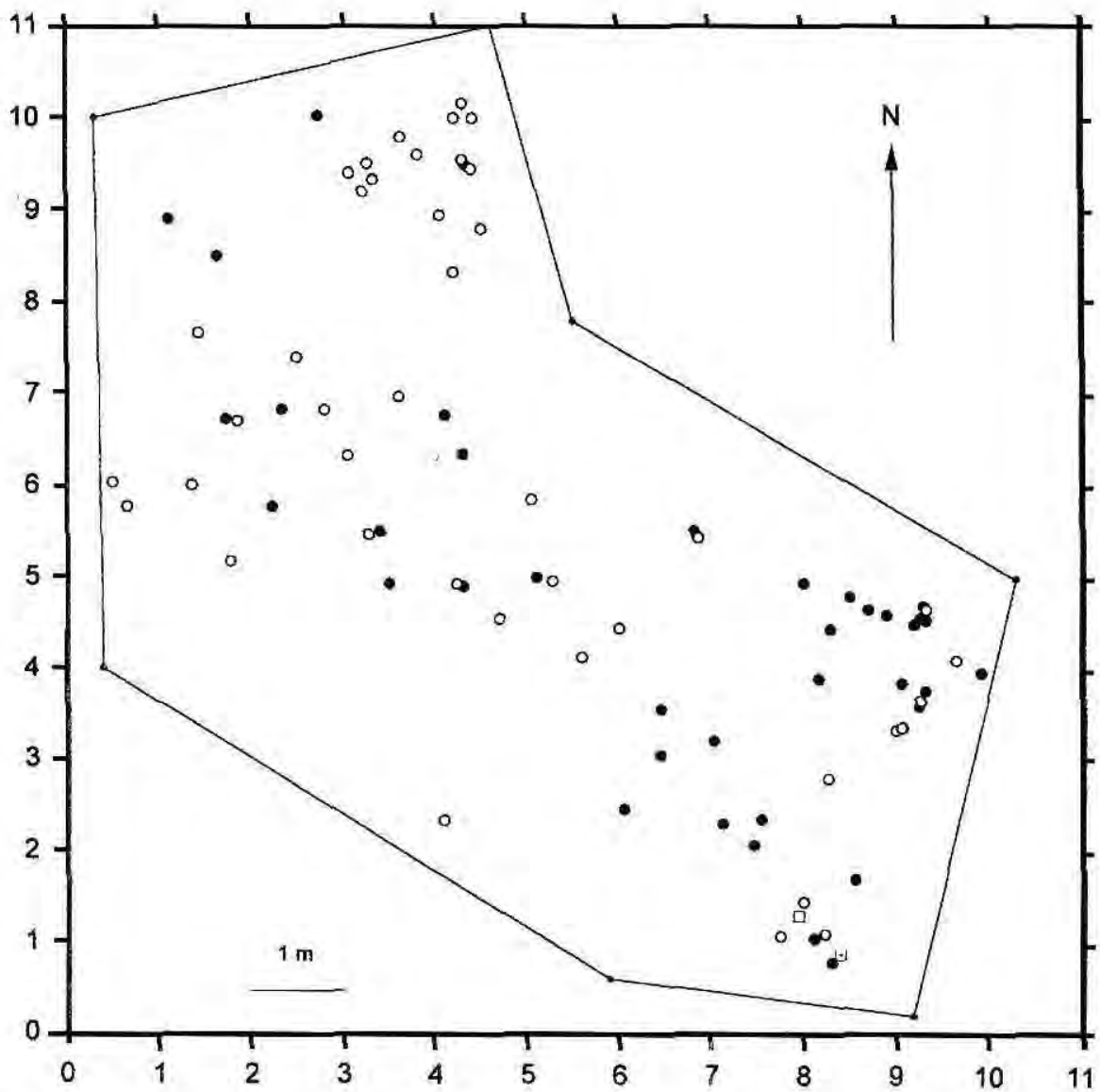

Figure 2. Nest entrance holes of Syntermes molestus and S. spinosus mapped in an area of $68 \mathrm{~m}^{2}$ in the Reserva Florestal Adolfo Ducke, Central Amazonia, during 2 weeks. This map shows all the 89 entrance holes existing at the end of the study. Filled circles = entrance holes made or last used by $S$, molestus; open circles $=$ entrance holes made or last used by $S$. spinosus. Squares: entrance holes which were initially used by $S$. molestus, and then taken over by $S$. spinosus. The foraging territories of the two species appear to over lap. 
ring beneath the surface.

\section{ACKNOWLEDGEMENTS}

This study was financed by Deutsche Forschungsgemeinschaft and logistically supported by INPA. Thanks are due to Joachim Adis, MaxPlanck-Institut Plön, Hubert Höfer, Staatliches Museum für Naturkunde, Karlsruhe, and Jo Darlington, University of Cambridge, who all gave valuable comments on a previous draft of this paper.

\section{Literature cited}

Bandeira, A. G. 1991. Térmites (Insecta: Isoptera) consumidores de liteira na Ilha de Maracá, Roraima. Acta Amazonica, 21: $15-23$,

Barbosa, R. I. 1993. Periodo de forrageamento de duas espécies de Syntermes (Isoptera, Termitidae) em uma floresta tropical amazônica e a relação com temperatura e umidade do ar. Revia. bras. Ent., 37(4): 763-767.

Chauvel, A.; Lucas, Y.; Boulet, R. 1987. On the genesis of the soil mantle of the region of Manaus, Central Amazonia, Brazil. Experientia, 43: 234-241.
Constantino, R. 1995. Revision of the neotropical genus Syntermes Holmgren (Isoptera: Termitidae). The University of Kansas Science Bulletin, 55(13): 455-518.

Darlington, J.P.E.C. 1995. Underground foraging passages and storage pits built by the termite Syntermes molestus in Goiania, Brazil (Isoptera: Termitidae). Sociobiology 23(2): 211-212

Höfer, H.; Martius, C.; Beck, L. (1996). Decomposition in an Amazonian rain forest after experimental litter addition in small plots. Pedobiologia, 40(6): 570-576.

Martius, C. (1998). Occurrence, body mass and biomass of Syntermes spp. (Isoptera: Termitidae) in Reserva Ducke, Central Amazonia. Acta Amazonica 28(3); 319-324.

Prance, G.T. 1990. The floristic composition of the forests of central Amazonian Brazil. In: Gentry, A.H. (ed.) Four Neotropical Rainforests. New Haven, Yale University Press, 112-140.

Ribeiro, A. 1991. Análise das variações climáticas observadas na região de Manaus (AM). M.Sc. thesis, University of São Paulo, São Paulo. 